\title{
The Concept and Features of Narcotic Drugs \\ in the Legal Turnover \\ as an Object of Legal Relations
}

\author{
Artyom D. Nevirko* \\ Siberian Institute of Law \\ Federal Drug Control Service of Russia \\ 20 Rokossovskogo Str., Krasnoyarsk, 660131, Russia
}

Received 21.11.2015, received in revised form 08.12.2015, accepted 14.03.2016

The article describes the features of narcotic drugs as an object of the legal turnover. The criteria of the demarcation of narcotic drugs from other medicines have been analyzed. The suggested concept of narcotic drugs reflects all the necessary features. Also the brief classification of narcotic drugs is given.

Keywords: concept of narcotic drugs, features of narcotic drugs, classification of drugs.

DOI: 10.17516/1997-1370-2016-9-4-1014-1022.

Research area: sociology.

The category "narcotic drugs" has not received a single interpretation both in everyday discourse and in science. Unfortunately, we cannot observe any uniform terminology here.

In daily use, the most common is the idea of drugs as potent substances, the consumption of which arouses pacification, euphoria and excitement ${ }^{1}$. From a philosophical point of view, drugs are seen as a form of matter, represented by things, objects of the material world, having relative independence and stable existence.

With regard to the subject of research of different branches of the social sciences, this category is given its own importance. For example, in medicine, combining theoretical principles with practical activities aimed at preserving and promoting human health, the extension of life, prevention and treatment of diseases, narcotic drugs mainly considered as a group of drugs that have analgesic and somnolent effect, abuse of which, or consumption without doctor's prescription leads to addiction ${ }^{2}$. According to the World Health Organization, the narcotic drug "is any material (substance), which, when introduced into a living organism, is capable of changing one or several of its functions and can cause psychic or somatic dependence"3.

In jurisprudence narcotic drugs are primarily investigated as an object (subject) of legal relationships. However, like any other matter in its philosophical sense, they have all the same properties that are characteristic of any thing.

(c) Siberian Federal University. All rights reserved

* Corresponding author E-mail address: onrio@yandex.ru 
But at the same time, these substances have such features which are peculiar to them as objects of social and legal rights. This is due to the fact that drugs, as the objects of legal relationships, including civil, must have the independence and stability at all stages of the development of an appropriate legal connection.

As the objects of legal relationships, the analyzed substances have the following features. First, they are the subjects of the real material world; they exist in a certain objectified form of things, and they are not the fruit of our mind and imagination. Second, like other things, investigated substances possess certain measures, in particular the weight and volume. Third, the drugs as material objects of the world include the results of human labour and natural objects used by people in their own interest. Finally, in the fourth, the substances have natural specific properties, virtue of which human consumption causes psychic and somatic changes in his body.

From the point of view of the theory of civil law and legislation, narcotic drugs apply to such objects of civil rights as a thing (Art. 128 of the Civil Code of the Russian Federation).

In a philosophical sense, a thing is a separate subject of the material world, which has a relatively independent and stable existence. The distinctness of a thing is determined by its structural, functional, quantitative and qualitative characteristics, its corporeality. The most common expression of the inherent characteristics of a thing, as V. Lapach notes, are its properties, and the place and role of a definite thing in a certain system are expressed through its relations with other things ${ }^{4}$.

In domestic legislation a quite clear distinction is drawn between the concept of things in a philosophical, physical, and legal sense. So, D. Meyer, describing the civil law deal, wrote that its subject must have a legal significance, represent a property interest in terms of the legal relationship of a man to the material world, be tradable, licit and ethic, and admit a physical possibility of performing actions to it ${ }^{5}$. Regarding the nature of things, E. Trubetskoy notes that " in the legal sense things should be understood as all the objects of the external non-free world, existing or expected in the future, which may be subjected to the rule of persons recognized as legal entities ... and can serve as means to their goals " 6 .

In modern civil law study things are understood as given by nature or man-made values of the material world, acting as objects of civil rights ${ }^{7}$. According to Ye. Sukhanov, things are material, physically tangible objects having the economic form of the product.

P. Avakyan identifies narcotic drugs as medications, raw materials, plants and their components containing such substances, whose consumption without doctor's prescription causes a painful addiction to them, and therefore they are prohibited by law for use in non-medical and scientific purposes ${ }^{8}$. It should be noted that the Single Convention on Narcotic Drugs of 1961 provides a number of drugs, prohibited for use in medical and scientific purposes.

According to D. Gazizov, narcotic drugs are substances (liquids) of synthetic or natural origin, medications, plants (or parts of plants) that affect the central nervous system (hallucinogenic, exciting effects and others), regular consumption of which causes enduring psychic and physical dependence (addiction), followed by the development of abstinence when you stop receiving, and formation of need to continue receiving ever-increasing doses (tolerance), which are in accordance with the normative and legal acts under control at the international or national level'.

S. Didovskaya connects the concept of narcotic drugs with two criteria: content and formal legal. In terms of the content criterion, narcotic drugs are the substances that have 
the ability to induce a state of euphoria when consumed, and the systematic consumption mental and physical dependence on the narcotic drug (addiction). The formal legal criterion implies that the specific narcotic drugs must be listed in the international law or domestic regulatory documents, otherwise this or that drug can not be considered narcotic. The content criterion is a reference point for including a substance on the list of narcotic drugs, and the formal legal criterion - for bodies implementing regulations in this sphere ${ }^{10}$.

Like other things, narcotic drugs for various indications can be assigned to certain groups, in respect of which certain features of legal regulation of the relevant property relations are set. Drugs are divisible things, because in a result of division they do not change their properties and original economic purpose. Further, they are consumable things, as completely lose their consumer qualities and the original form in a single use (consumption). Narcotic drugs are things defined by generic signs, for their individualization in the civil turnover is realized by specifying their generic belonging, qualitative state and quantitative measure.

So, we can conclude that drugs are the objects of the material world, characterized by specific properties and able to meet the needs of the subjects of law, controlled by them and be in their possession.

In legal literature there are three criteria which characterize the features of drugs: target (use in medicine for diagnosis, prevention, treatment of diseases and prevention of unwanted pregnancy); social (the social significance of drugs and the potential threat to the health of citizens); legal (the system of measures, funds and bodies, through which the proper quality control and safety of medicines are ensured $)^{11}$.

We completely share the denoted position, and offer to use these features similarly to narcotic drugs. The target criterion means that the substance must have a specific (stimulant, sedative, hallucinogenic and other) effect on the central nervous system and this is the reason for its non-medical application. The social criterion implies that non-medical use of the reviewed substance acquires such proportions that it becomes socially significant.

The legal criterion comes from both of the above premises and demands that the relevant authority must admit that this substance requires special legal regulation and must be included in the list of narcotic drugs and psychotropic substances.

A. Mokhov, exploring drugs, comes to the conclusion that in accordance with the degree of harmful properties we can distinguish drugs, which are a source of increased risk (having severe harmfulness) and which are not a source of increased risk (having no severe harmfulness) ${ }^{12}$.

Accepting this statement, we emphasize that narcotic drugs should certainly be referred to high-risk sources.

But can it be limited by such a definition of the substance in relation to the legal regulation of public relations? Certainly no. The point is that the category "drugs" is a collective term that includes a wide variety of substances and products, the consumption of which involves varying degrees of manifestation of psychic or somatic changes in the body of an individual. Therefore, such interpretation is uncertain, too broad and unacceptable for the law. Based only on the medical (pharmaceutical) effects of human consumption of these substances, it is hardly appropriate to talk about the legal regulation of the forming social relations concerning drugs.

Nor can we agree with some lawyers who propose the definition of "drugs", which focuses on the psycho-physiological effects of changes in the individual citizen who uses them, and retains uncertainty regarding narcotic drugs. The position 
of F. Razarenov can serve as an example of such an approach to the formulation of the analyzed concept, according to which the narcotic drugs are recognized as "substances of plant (organic) or synthetic origin which have intoxicating effects or cause euphoria when used"13.

The correction of the definition is possible by pointing out the specific substances, possessing narcotic properties. In this way the international and national legislation on drugs is being formed.

Therefore, narcotic drugs are not any substance or drug having these properties, but only those which are in some way related by the legislator to this category. Depending on the functionalpurpose oflegalregulation, it is achieved by compiling a Schedule of such substances, as established by the Single Convention on Narcotic Drugs of 30 March 1961, the Vienna Convention on Psychotropic Substances of 21 February $1971^{14}$ and the Federal Law of 8 January 1998 № 3-FZ “On Narcotic Drugs and Psychotropic Substances"15. In accordance with this, legal connections can be formed either in relation to drugs in general or to their individual kinds (varieties), or narcotic substances.

At the international level of legal regulation of the narcotic drugs turnover, their schedule is given in the annexes to the Single Convention on Narcotic Drugs of 1961 and the Vienna Convention on psychotropic substances of $1971^{16}$, a participant of which is the Russian Federation. The Convention contains 4 Schedules of narcotic drugs, distributed depending on the mode used to control them.

The purpose of these Conventions is the codification of the universally applicable control measures and theprovisionof thenecessary amount of narcotic drugs and psychotropic substances for medical and scientific purposes, as well as not allowing their diversion from legal sources to illegal channels. The Vienna Convention against
Illicit Traffic in Narcotic Drugs and Psychotropic Substances of 20 December, $1988^{17}$ provided additional measures against drug trafficking and forms of international cooperation in this field.

Similarly, this issue is resolved in the national legislation. According to Art. 2 p. 1 of the Federal Law "On Narcotic Drugs and Psychotropic Substances", narcotic drugs, psychotropic substances and their precursors, subject to control in the Russian Federation, are included in the Schedule of narcotic drugs, psychotropic substances and their precursors (hereinafter - the Schedule ). Depending on the applicable state controls within the Schedule, they are grouped into separate lists.

In accordance with Art. 2 p. 2 of the Federal Law mentioned above, the Schedule is approved by the Government of the Russian Federation on the proposal of the federal executive authority in the field of health care and the federal executive authority in the field of internal affairs. As a result, the principle contradiction for the law enforcement practice has been eliminated, because earlier the Schedule, and together with it, the issue of bringing to criminal responsibility, was decided on the basis of recommendations of the Permanent Drug Control Committee, Ministry of Health, which does not possess public authority status.

The current Schedule was approved by the RF Government Decree of 30 June 1998 № $681^{18}$. It consists of four lists.

Subject to control in the Russian Federation narcotic substances, psychotropic substances and their precursors are included in the Schedule of narcotic drugs, psychotropic substances and their precursors subject to control in the Russian Federation, and depending on the state control measures, are brought in the following lists:

the list of narcotic drugs, psychotropic substances and their precursors, the turnover of which is prohibited in the Russian Federation in 
accordance with the legislation of the Russian Federation and international treaties of the Russian Federation (hereinafter - List I);

the list of narcotic drugs and psychotropic substances, the turnover of which is restricted in the Russian Federation, and in respect of which control measures are established in accordance with the legislation of the Russian Federation and international treaties of the Russian Federation

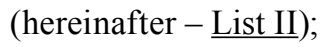

the list of psychotropic substances, the turnover of which is restricted in the Russian Federation, and in respect of which the exclusion of certain control measures is allowed in accordance with the Russian Federation and international treaties of the Russian Federation legislation (hereinafter - List III);

the list of precursors, the turnover of which is restricted in the Russian Federation, and in respect of which control measures are established in accordance with the legislation of the Russian Federation and international treaties of the Russian Federation (hereinafter - List IV), comprising several precursors tables.

This List was compiled for the first time, as the Permanent Drug Control Committee had not given the list of precursors. It included individual catalysts and solvents used in the production, manufacture, processing of narcotic drugs and psychotropic substances.

At first glance it may seem that the criterion for the inclusion of drugs in one or the other List is the degree of hazard (the effect on the human body, the rate of occurrence of physical addiction and others.). But this is not the case. It is known that drugs, made on the basis of the opium poppy, are the most dangerous (physical addiction occurs after $6-8$ times, the average life expectancy of heroin addicts is $5-7$ years). It is a different situation with marijuana. There is a perception that cannabis and its derivatives (hashish) are far less dangerous than tobacco,
${ }^{19}$ nevertheless, they are in the same List with heroin.

Analyzing the Schedule, one can conclude that when a substance was included in one or the other List, first of all its medical (pharmacological) value was taken into account, that is, the possibility of its use for the prevention, diagnosis and treatment of diseases. In this regard, narcotic drugs were initially divided into two groups: prohibited for use to human beings and authorized for use by the Ministry of Health of Russia. In List I there were narcotic drugs and psychotropic substances, prohibited for sowing, cultivation, and for use to humans. And narcotic medicinal substances were included in Lists II and III.

Including drugs in Lists II and III, the risk of their non-medical consumption was taken into account, i.e. speed of emergence of physical addiction, effects on the central nervous system and on the human body as a whole. Based on these criteria, List II includes the most dangerous in its effect narcotic drugs and psychotropic substances, and, therefore, strict controls are set for them. List III includes narcotic drugs and psychotropic substances which are less dangerous, thus some exclusion of certain control measures are allowed for them.

According to Art. 25 of the Federal Law "On Narcotic Drugs and Psychotropic Substances", narcotic medical substances and psychotropic drugs are provided for individuals only in pharmaceutical companies, or medical institutions, or separate subdivisions of medical institutions located in rural areas and remote from populated centers, where there are no pharmacy institutions, if pharmaceutical companies, medical institutions and their separate subdivisions have got the license for this specified activity.

The schedule of positions of pharmaceutical and health care workers in the institutions that have been granted the right to release the narcotic 
drugs and psychotropic drugs to individuals, are established by the federal body of the executive authority responsible for the development and implementation of the state policy and normative legal regulation in the sphere of public health. Narcotic drugs and psychotropic substances included in Lists II and III are released (sold) for medical purposes on prescription. A prescription for a medicinal product is a written order for the drug in the prescribed form, issued by the eligible medical or veterinary worker for selling or producing and selling the drug ${ }^{20}$.

In summary it is possible to propose the following concepts. Narcotic drugs in the legal turnover are substances (objects) of the material world of natural or synthetic origin, included in the special schedule of drugs established by law and which may be in the possession of a person, able to meet the needs of the subjects of law, and the repeated consumption of which, due to their properties, causes psychical or somatic changes in the human body, and which are provided for medical purposes by prescription.

In jurisprudence and practice of law application, the differentiation of narcotic drugs in certain types is carried out on various criteria. Thus, on the ground of origin it is customary to distinguish natural (organic) and synthetic kinds of drugs. The natural narcotic drugs are those substances which are given by nature. The narcotic drugs of synthetic origin are produced by reactions out of chemicals, including those with broad usage.

Since the natural types of narcotic drugs have been obtained mainly from plants, in practice they are quite often referred to as drugs of plant (organic) origin. They include those which are prepared from drug-containing plants, for example from opium poppy. It seems that such an approach is not justified, as it helps narrow down the natural types of drugs.
Differentiation of drugs for certain types also depends on the particular effects on the human body and the manifestation of their psychoactive properties in the human body. In accordance with this, they are usually divided into narcotic drugs and psychotropic substances. However, it should be noted that either in law or in legislature such a differentiation of the substance has not got proper development.

Quite often the legislator, both at the international and national levels, formulating the rules of law, uses the nouns "drug" or "substance" with the adjectives "narcotic" and "psychotropic" in various, sometimes random, combinations. Mostly, it doesn't influence the efficiency of legal regulation of relations concerning narcotic drugs, because it can only mean the substances that mentioned in the appropriate list of narcotic drugs. However, the diversity of terminology in this field of legal regulation does not promote the development of a clear conceptual and categorical apparatus of legal regulation of the drug turnover.

Trying to eliminate these problems, the legislator attempted to formulate a legal definition of the main types (groups) of drugs, as well as their varieties. According to Art. 1 of the Federal Law "On Narcotic Drugs and Psychotropic Substances" as such are:

narcotic drugs are substances of synthetic or natural origin, drugs, included in the Schedule of narcotic drugs, psychotropic substances and their precursors, which are under control in the Russian Federation, in accordance with the legislation of the Russian Federation, international treaties of the Russian Federation, including the Single Convention on Narcotic Drugs of 1961;

psychotropic substances are substances of synthetic or natural origin, drugs, natural materials, included in the Schedule of narcotic drugs, psychotropic substances and their precursors, which are under control in the 
Russian Federation in accordance with Russian legislation, international treaties of the Russian Federation, including the Convention on Psychotropic Substances of 1971;

precursors of narcotic drugs and psychotropic substances (hereinafter - the precursors) are substances frequently used in the production, manufacture, processing of narcotic drugs and psychotropic substances, included in the Schedule of narcotic drugs, psychotropic substances and their precursors, which are under control in the Russian Federation in accordance with the legislation of the Russian Federation, international treaties of the Russian Federation, including the United Nations Convention Against Illicit Traffic in Narcotic Drugs and Psychotropic Substances of 1988;

analogues of narcotic drugs and psychotropic substances are substances of synthetic or natural origin, prohibited for the turnover in the Russian Federation, not included in the Schedule of narcotic drugs, psychotropic substances and their precursors, that are under control in the Russian Federation, the chemical structure and properties of which are similar to the chemical structure and the properties of the narcotic drugs and psychotropic substances, the psychoactive effect of which they reproduce.

According to its legal regime, narcotic drugs, like other objects of civil rights, may be assigned to one or another group of things (Art. 129 of the Civil Code). In particular, narcotic drugs which are included in List I of the Schedule, approved by the Government Resolution dated June 30, 1998, belong to the category of things withdrawn from the turnover, and those specified in Lists II-IY, are limited in the turnover. At the same time narcotic drugs, as objects of civil rights, occupy a special place among the things because of their properties and effects of human consumption. This fact determines the peculiarity of their transferability, which requires independent study.

See: Ozhegov S.I. Russian Dictionary: 70000 words/ edited by Shvedova N. Yu. $23^{\text {rd }}$ edition. Moscow, 1991. P.389.

See: Popular Medical Encyclopedia. Chief Editor Pokrovsky V. I. $3^{\text {rd }}$ edition. Moscow, 1991.

Quote by: Serdyuk L. V. Issues of Improvement of Fight against Drug and Toxic Substance Addiction // Actual Problems of Improving the Criminal Law: interuniversity collection of scientific works. Khabarovsk, 1988. P.53.

4 Lapach, V. A. System of Objects of Civil Rights: Theory and Judicial Practice / Publisher "Legal Center PRESS", St. Petersburg, 2002. P. 544.

Meyer D. I. Russian Civil Law. Part 1 P.180-182.

Trubetskoy Ye. N. Encyclopedia of Law. St. Petersburg University, 1998. P.180-182.

Civil Law: Textbook Part I, $2^{\text {nd }}$ edition/ edited by Sergeev A. P. , Tolstoy Yu. K. Moscow, Prospekt, 1996. P.196.

Avakyan R. O. Drug Addiction and Methods of Fight against It/ Avakyan R. O.: Yerevan, 1990. P. 14.

Gazizov D. A. Administrative and Legal Bases for the Prevention and Suppression of Crime by the Police in the Field of Narcotics Trafficking: the thesis of candidate of legal sciences/Gazizov D. A.: Omsk, 1998. P.39.

10 Didovskaya S. P. Drug Addiction (Criminal, Legal and Medical Problems)/ Didovskaya S.P., Fesenko E.V., Garnitsky S.P.: Kiev, 1989. P.69.

11 Mokhov A.A. Medicinal Products as Objects of Civil Rights // Lawyer. 2004. № 12. P.54

12 Mokhov A.A. Poor Quality Health Service as a Source of Increased Danger to Others // Modern Law. 2004. №10. P.2-5.

13 See: Administrative Activity of Internal Affairs Bodies. Special Part: Textbook / Edited by Korenev A.P. Moscow, 1998. P. 87.

14 The Legal Basis of Organization of Fight against Drug Trafficking: Collection of Normative Acts and Methodological Materials / Edited by Menshikh N.V. Moscow, 1998.

15 Collection of Laws of the Russian Federation. 1998. № 2. P. 219.

16 The Legal Basis of Organization of Fight against Drug Trafficking: Collection of Normative Acts and Methodological Materials / Edited by Menshikh N.V. Moscow, 1998. P. 3-17.

17 The Legal Basis of Organization of Fight against Drug Trafficking: Collection of Normative Acts and Methodological Materials / Edited by Menshikh N.V. Moscow, 1998. P. 17-23.

18 Code of Laws of the Russian Federation. 1998. № 27. P. 3198.

19 Kuznetsov D.O. Narcotic Drugs as a Social Problem and its Solutions in Russia // Theory and Practice of Counteraction of Drug Addiction in the Urals Region. Issue 2. Yekaterinburg, 1998.

P. 22.

20 Medical Law of Russia: textbook for undergraduates / Edited by Mokhov A.A. Moscow: Norma: INFRA_M, 2015. P.268. 


\section{References}

Avakyan, R.O. Narkomania i metody borby s neyu [Drug Addiction and Methods of Fight against It]. Avakyan R. O.: Yerevan, 1990. 14 p.

Administrativnaya deyatelnost organov vnutrennikh del. Chast osobennaya: uchebnik [Administrative Activity of Internal Affairs Bodies. Special Part: Textbook] Edited by Korenev A.P. Moscow, 1998. $87 \mathrm{p}$.

Gazizov, D.A. Administrativno-pravovye osnovy preduprezhdeniya i presecheniya militsiey pravonarusheny $v$ sfere oborota narkoticheskikh sredstv:dis. kand. yurid. nauk [Administrative and Legal Bases for the Prevention and Suppression of Crime by the Police in the Field of Narcotics Trafficking: the thesis of candidate of legal sciences] Omsk, 1998. $39 \mathrm{p}$.

Grazhdanskoye pravo: uchebnik [Civil Law: Textbook Part I, $2^{\text {nd }}$ edition]. Edited by Sergeev A.P., Tolstoy Yu. K. Moscow, Prospekt, 1996. 196 p.

Didovskaya, S.P. Narkomaniya (Ugolovno-pravovye i meditsinskie problemy) [Drug Addiction (Criminal, Legal and Medical Problems)] Kiev, 1989. 69 p.

Kuznetsov, D.O. Narkotiki kak sotsialnaya problema i puti yeyo reshenia v Rossii. Teoria $i$ praktika protivodeistvia narkomanii v Uralskom regione [Narcotic Drugs as a Social Problem and its Solutions in in Russia, Theory and Practice of Counteraction of Drug Addiction in the Urals Region.] Issue 2. Yekaterinburg, 1998. $22 \mathrm{p}$.

Lapach, V. A. Sistema obyektov grazhdanskikh prav: teoria i sudebnaya praktika [System of Objects of Civil Rights: Theory and Judicial Practice] Publisher "Legal Center PRESS", St. Petersburg, 2002. $544 \mathrm{p}$.

Meyer, D. I. Russkoye grazhdanskoye pravo. [Russian Civil Law.] Part 1 180-182p.

Mokhov, A.A. Lekarstvennye sredstva kak obyekty grazhdanskikh prav Yurist. [Medicinal Products as Objects of Civil Rights], Lawyer. 2004, 12, 54 p.

Mokhov, A.A. Nekachestvennoye meditsinskoye obsluzhivanie kak istochnik povyshennoi opasnosti dlya okruzhayushchikh, Sovremennoye pravo [Poor Quality Health Service as a Source of Increased Danger to Others], Modern Law. 2004. 10, 2-5 p.

Meditsinskoye pravo Rossii: uchebnik dlya bakalavrov [Medical Law of Russia: textbook for undergraduates], Edited by Mokhov A.A. Moscow: Norma: INFRA_M, 2015. 268 p.

Ozhegov, S.I. Slovar Russkogo yazyka: 70000 slov [Russian Dictionary: 70000 words]. Edited by Shvedova N. Yu. $23^{\text {rd }}$ edition. Moscow, 1991. 389 p.

Populyarnaya meditsinskaya entsiklopedia [Popular Medical Encyclopedia]. Chief Editor Pokrovsky V. I. $3^{\text {rd }}$ edition. Moscow, 1991.

Pravovaya osnova organizatsii borby s nezakonnym oborotom narkotikov: Sbornik normativnych aktov i metodicheskich materialov. [The Legal Basis of Organization of Fight against Drug Trafficking: Collection of Normative Acts and Methodological Materials]. Edited by Menshikh N.V. Moscow, 1998.

Sbornik Zakonodatelstva RF. [Collection of Laws of the Russian Federation], 1998, 2, 219 p. 3198 p.

Serdyuk, L. V. Voprosy sovershenstvovania borby s narkomaniei $i$ toksikomaniei. Aktualnye problemy sovershenstvovania ugolovnogo zakonodatelstva: mezhvuzovsky sbornik nauchnykh trudov. [Issues of Improvement of Fight against Drug and Toxic Substance Addiction, Actual Problems of Improving the Criminal Law: interuniversity collection of scientific works.] Khabarovsk, 1988, 53 p. 
Trubetskoy Ye. N. Entsiklopedia prava. [Encyclopedia of Law.] St. Petersburg University, 1998. 180-182 p.

\title{
Понятие и признаки
}

\section{наркотических средств в легальном обороте как объекта правоотношений}

\author{
А.Д. Невирко, \\ Сибирский юридический институт \\ ФСКН России \\ Россия, 6600131, Красноярск, ул. Рокоссовского, 20
}

В статье рассмотрены признаки наркотических средств как объекта легального оборота. Проанализированы критерии отграничения наркотиков от иных лекарственных средств. Предложено понятие наркотиков, которое отражает все необходимые признаки. Также дана краткая классификация наркотиков.

Ключевые слова: понятие наркотических средств, признаки наркотических средств, классификаиия наркотических средств.

Научная специильность: 22.00.00 - социологические науки. 